2017 , volume 6, issue 4

Sitorus, T., \& Denny (2017). The influence of asset and profitability toward share value: Mediation Effect Of Liquid Asset. Copernican Journal of Finance \& Accounting, 6(4), 85-103. http://dx.doi. org/10.12775/CJFA.2017.024

\author{
Tigor Sitorus*
}

Universitas Bunda Mulia, Jakarta

DENNY**

Universitas Bunda Mulia, Jakarta

\title{
THE INFLUENCE OF ASSET \\ AND PROFITABILITY TOWARD SHARE VALUE: MEDIATION EFFECT OF LIQUID ASSET
}

Keywords: asset, profitability, liquid asset, value of share.

\section{J E L Classification: G32.}

\begin{abstract}
The purpose of this research is to extend the relationship between asset and profitability with share value and this study also aims to find out the factors that influence of the value of share and propose the Liquid Asset as the intervening variable for filling the gap of prior research within the mining sector listed on the Indonesian Stock Exchange from the period of 2010 to 2014. This research used quantitative approach with a descriptive method by using secondary data in the form of financial report of the mining sector. The population in this study is all mining sector companies listed on the Indonesian Stock Exchange. The sample was taken using purposive sampling method and obtained 20 companies that met the criteria of sampling, while the observational data that could be collected was 100 within 2010-2014 (5 years). This research used the data analysis method of Structural Equation Modelling path. The results of this stu-
\end{abstract}

Date of submission: April 16, 2018; date of acceptance: May 10, 2018.

* Contact information: sitorus_tigor@yahoo.com, Universitas Bunda Mulia, Jakarta, Taman Century I L/6 Bekasi, Indonesia, phone: 6281514054090; ORCID ID: https://orcid.org/0000-0001-7477-9537.

** Contact information: dnymoe@gmail.com, Universitas Bunda Mulia, Jakarta, Indonesia. 
dy prove that all hypotheses are accepted, so it can be concluded that the result evidently shows that the Liquid Asset is able to mediate the influence of asset and profitability toward value of share.

\section{IINTRODUCTION}

The mining sector is one of the pillars of a country's economic growth because up to now this sector has become a mainstay of a country with abundant natural resources and the world market demand for mining is still very high. The rich natural resources potential will encourage more companies to explore mining resources but mining companies desperately need large capital to engage in exploration and exploitation activities. To get a lot of capital, mining companies must sell their shares in the stock market, such as the Indonesia Stock Exchange (IDX).

The mining sector on the Indonesia Stock Exchange is one of the most reliable sectors because Indonesia is a country rich in natural resources.

Based on data from the Indonesia Stock Exchange as of January 2015, mining sectors consist of coal mining sub-sectors which are 22 companies that include crude oil sub-sector and natural gas 9 companies, metal and mineral mining sub-sector 8 companies and stone mining sub-sector 4 companies (www1).

Mining companies enter the capital market to absorb funds in the form of investments from investors and to strengthen their financial position, and therefore the capital market has also a major role for the economy of a country because the capital market serves two functions at once, which are economic and financial. The capital market is said to have a market economy function because it provides a facility that brings together two parties with the interests of funding and a need of funds. Below, the authors present the average stock price in the mining sub-sectors listed on the Indonesia Stock Exchange (IDX) for the period of 2010 to 2014 which can be seen in the following figure.

From the graph above we can see that in the average share value from 2010 to 2014 , coal had the largest share value compared to oil \& gas, metals \& minerals, and stone \& land meanwhile based on the survey of LQ45 in 2015, the mining sectors were only held by 5 companies among the top 45 positions or shares with the highest intensity of transactions in Indonesia. 
Figure 1. Stock Price Curve of Mining Sectors

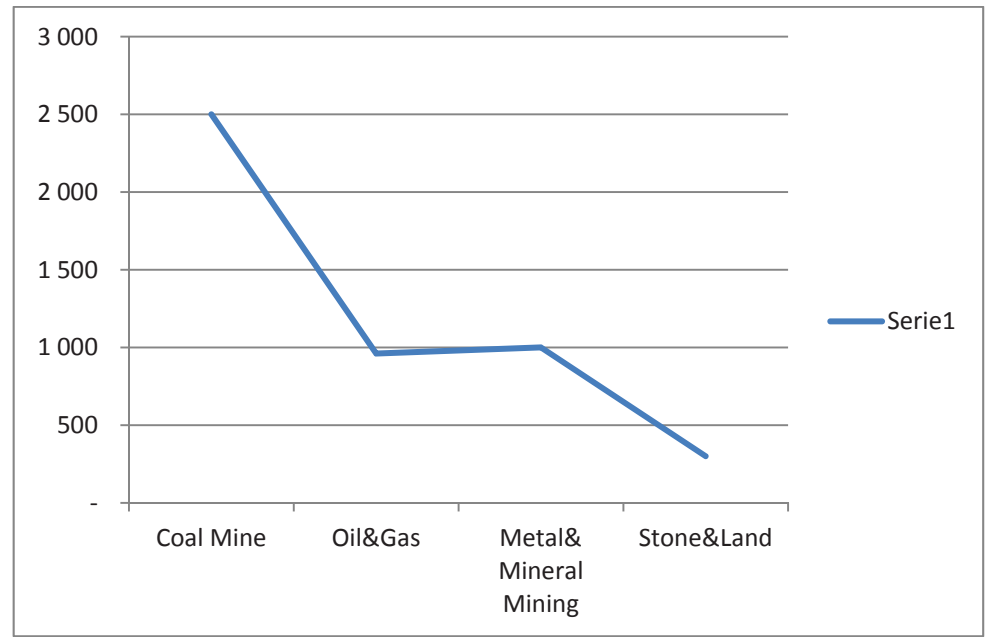

IDR (Indonesian Rupiah)

S o u r c e : own study based on: www1.

Empirically, some experts have stated that the value of stock is influenced by many factors. According to Alwi (2003, p. 87), there are two factors that could affect the stock price, namely internal and external factors. The internal factors in this case is when a change or turmoil that occurs in the internal part of the company will impact the movement of stock price of the related company. Alwi also suggested that (2003, p. 87) in addition to the internal factors, external factors also have influence on the development of stock price of a company. The factors that become the trigger of the movement of stock prices are asset development and profitability as they affect the value of the company's stock.

Kieso, Weygandt and Warfield (2011) stated that asset is a source of income for the company's business and asset is a possible future economic gain that can be obtained as a result of past transactions or events. From these definitions of asset, we can see that there is a relationship between asset and the value of the related competitiveness of the share. If an investor intends to invest in a company, the investor will search a company whose assets have high value, so that the investor can get benefits or advantages over the investment made in the company. Asset is a possible economic advantage that may be presented 
by the company and for investor it is a source of funds and thus there should be a win-win solution for both parties.

Large-scale companies like mining companies in general will certainly attract investors if they have liquid asset for the short term and sufficient advantage for the long term. Regarding with profitability of a company, according to Elmi and Muturi (2016), a company must have definite profit because profitability is a significant factor in determining dividend payout, and poor performance of profitability will definitely affect payout negatively. Such condition will certainly distract the potential investor to invest.

Damyanti and Achyani (2006) stated that a company will continue to improve their value if they can grow their assets and it can be obtained by increasing their profitability. Increasing profitability will affect the adequacy of liquid asset.

Liquid Asset is also a measure that indicates whether a company can pay dividend as a liability to investor or not. If a company has large net cash, it will become a good sign for investor to get future cash so that the investor has a sense of security in investing in that company. This is inseparable from the roles of asset and profitability that sustain the activities of a company so that it is suspected that Liquid Asset has an influence in bridging the asset and profitability in affecting the value of the stock that leads to the interests in buying or selling shares of the related company.

This research tries to develop the influence of asset which is represented by total assets and profitability that is represented by net profit margin to share value that is represented by stock closing price through filling up the variabel liquid asset as mediating variable. Liquidity is very important for the firm as an assurance that the firm is able to pay the dividend. For example, in 1997-1998, a number of companies in Asia faced a liquidity crisis and bankruptcy (Yoo \& Kim, 2015).

This research is different from the research conducted by Ghauri (2014) that found out that asset has a significant influence on share value and by F.N. Al-Shubiri (2010, p. 137) who showed a significantly positive relationship between net asset value and stock price. In another research Sitorus (2016) examined the influence of mediation that is done by the company on the influence of profitability on the value of stock. In this study, researchers try to propose variable of liquid asset as filler of research gap in relation between asset and profitability to value of share. 
Based on the phenomenon and research gap mentioned above, the purposes of this research and also the hypotheses that will be proved in the discussion of this study are: (1). Does asset have a positive influence on the liquid asset? (2) Does profitability have a positive influence on the liquid asset? (3) Does asset have a positive influence on value of share? (4) Does profitability have a positive influence on value of share? and (5) Does the liquid asset have a positive influence on value of share.

\section{REVIEW OF LITERATURE}

\section{Asset}

According to Warren, Reeve and Fess (2005), assets are resources owned by business or business entities. These resources can be physical or economic. Assets are divided into two parts: Current Assets and Non-Current Assets (Kieso, Weygandt \& Warfield, 2011).

According to Dyckman, Davis and Dukes (2001), current assets include cash and other assets that are estimated to be realized to be cash or sold or used during one normal operating cycle of the company or within one year from the balance sheet date (one of the longer ones). Included in current assets are cash, temporary investment, notes receivable, accruals receivable, inventory, and prepaid expense.

\section{Profitability}

Profitability is the ability of gaining profits by the company within a certain period. The basis of profitability assessment is the financial statements consisting of the balance sheet and corporate income statements. Based on these two financial statements, the results of the analysis of a number of ratios will be determined and the ratio is then used to assess certain aspects of the company's operations. Profitability is the company's ability to generate profits and measure the level of operational efficiency in using its asset. Profitability is a description of the performance of the company's management. Profitability measurement can use several indicators such as operating profit, net profit, investment return/asset return and owner's equity return, and return on profit or return on investment that has been invested in a company (Hermuningsih, 2013, p. 131). 
Samy Ben Naceur (2003) stated that variations in the determination of a company's profitability become very important to be controlled by the management because they are influenced by the external factors that may affect the company's financial performance. Thus, the determinants influencing profitability can be identified to formulate policies to improve the profitability of a company.

According to Ulupui (2008) profitability can be assessed using several performace measure but still in the relevant dimension such as Return on Investment (ROI) and Return on Asset (ROA), which are related to profit and investment and asset used to produce them. The profitability ratio itself consists of two types, the ratio showing profitability in relation to sales (gross profit margin and net profit margin), and profitability in relation to investments ie Return on Asset (ROA) and Return on Equity (ROE). Furthermore researcher said that profitability will affect company ability to pay dividend to shareholder, this will have positive impact to company value which is indicated by high stock value (Elmi \& Muturi, 2016).

\section{Liquid Asset}

Stice, Stice and Skousen (2009) stated that profit is a return on investment for the owners. It measures the value that an entity can still afford to possess the same wealth as its original position. They further said that cash is the most liquid current asset and consists of parts that act as a means of exchange and provides a basis for accounting calculation. Meanwhile, according to Suwardjono (2008, p. 464) profit is interpreted as a reward for the company's efforts in producing goods and services. Furthermore, Chariri and Ghozali (2007) stated that the report of net income can be used as an indicator of the company's funds efficiency that are embodied in the rate of return, company's performance, as well as control of the allocation of company's economic resources, and it is also related to the basis of compensation and the distribution of bonuses in a company. On the other hand, cash also serves as a means of motivation management in controlling the company, and most importantly as the basis of dividend distribution to the investors who invest their shares in related company.

Cash and cash equivalents in the form of investments are considered very liquid and short term and can be immediately used as cash in certain amount without facing the risk of significant value changes (Mulya, 2010). Having the same idea, Stice, Stice and Skousen (2009) also said that cash equivalents are very liquid short-term investments that can be exchanged for cash. 


\section{Share Value}

According to Brigham and Houston (2010), the ratio of market value is a set of ratios that relate the firm's stock price to its earnings, cash flow and book value per share. Meanwhile, stock prices are maximizing shareholder value translated to maximize the firm's stock price. The stock price at one particular time depends heavily on the cash flow expected to be received in the future by the "average" investor if the investor buys the stock.

When a company issues one type of stock, it is called a common stock. If there are two kinds of shares issued, one is the common stock and the other is the preferred stock (Baridwan, 2004) with the following descriptions: (1). Ordinary shares (common stock) are the most heavily traded securities in the capital market. The holders of these securities have voting rights in the Shareholders General Meeting (AGM) and obtain dividends from the company as well as the possibility of gains on the increase of the capital (value) of such securities or capital gains. Ordinary shares carry the greatest risk because ordinary shareholders receive dividends after the dividends of preferred stock are paid. (2). Preferred Stock or Preferred Shares are often also referred to as privileged shares because preferred stock gets priority rights in the dividend distribution before dividend of common stock. If the company is liquidated, preferred shareholder also gets priority of claim on company asset after obligation to bondholder and other creditors are met before any claim by ordinary shareholders.

\section{THE RESEARCH METHODOLOGY AND THE COURSE OF THE RESEARCH PROCESS}

\section{Research design}

This study used a type of causative descriptive research. According Sugiyono (2011), descriptive method is a method used to describe or analyze a research result but not to make a wider result. Descriptive research method is a method used in a research with the aim to create a description and a systematic picture of meaning and nature, and the influence between the phenomena investigated. Causative research is a research used to determine the influence of one variable with other variables and how one variable affects other variables so this type of research aims to analyze the cause of influence between independent variable and dependent variable (Sugiyono, 2011). The data used in this study 
are secondary quantitative data from the financial statements of companies engaging in the field of mining listed on the Indonesia Stock Exchange (IDX). Meanwhile, the secondary data are obtained from other parties in the form of data that have been published to the public and quantitative data are the data in the form of numbers. Thus, the researchers can conclude that the type of research used in this study is descriptive causative research using secondary quantitative data.

Objects studied in this study are companies that engaged in the mining industry listed on the Indonesia Stock Exchange (BEI) within a period from 2010 to 2014 .

\section{Research variable}

According Kerlinger (1973, in Sugiyono, 2011), variable is the construct or the nature to be studied. The research variables used in this research are as follows:

1) The independent variables which are: asset value (X1) which is indicated by the ratio of current asset and fixed asset, (Kieso et al., 2011), Warren et al. (2005), and profitability (X2) which is indicated by net income, ROA, ROE, (Ulupui, 2008).

2) The dependent variables which are: the value of stock (Y2) represented by share price at the time of closing of transactions till end of year, Brigham and Houston (2010).

3) Mediation variables which are: liquid asset (Y1) that is represented by ratio of net cash flow, Stice, Stice and Skousen (2009).

\section{Population and Sample}

Population is a collection of objects that become the center of attention from which the necessary information will be obtained. This object is called the unit of analysis. This unit of analysis has similar behavior or characteristics to be studied. The population in this study is based on the data from $43 \mathrm{~min}$ ing sector companies listed on the Indonesia Stock Exchange (IDX) for a span of 5 years resulting in 215 observational data.

Sample is an example or subset of a population that is considered as the representative of the population so that any information generated from this sample may be considered representative of the entire population. After the test of 
outlier and data reduction, the researcher took 20 samples out of 43 companies for the span of 5 years that produced 100 observation data.

\section{Data source}

Data collection method in this research is non-behavioral observation method where data collecting is done by observing, recording, and studying the descriptions of journals, books and documents. In this study, reseachers observed, recorded, and studied the documents in the form of financial statements of companies engaging in mining sector from the period 2010 to 2014 that were listed on the Indonesia Stock Exchange (IDX). The financial statements that were studied such as current assets, fixed assets, ROA, ROE, net income, and net cash (www1). As for share value data, researchers used stock report value data sourced from Yahoo Finance (www2).

\section{Data analysis technique}

To analyze the influence between variables, this study used testing model of Structural Equation Modeling (SEM). The testing of the influence between variables in this study used research hypotheses produced by the SEM model of path analysis, and the processing of data used software AMOS 21. SEM is a multivariate statistical analysis tool that combines factor analysis with analysis path. The SEAM model is considered appropriate to examine the complex influence of variables. Basically SEM is a confirmatory statistical methodology such as hypothesis testing on multivariate analysis using structural theory. The SEM equation model is a model for analyzing the forces and causalities between variables described in the SEM Model, where each dependent variable is uniquely determined by a set of independent/exogenous variables (Riduwan \& Kuncoro, 2012).

\section{RESUlts AND CoNSLUSion}

The objective of the study was to find out whether profitability influences the liquid asset and impacts the share value of mining companies in Indonesia. The objective was tested through six (6) composite measures on a scaled ratio. The results findings are presented in table 1 (model testing) and table 2 (Hypotheses testing) as bellow. 


\section{Model Testing}

For testing the feasibility of Full Model, it can be seen in the table 1 bellow:

Table 1. Goodness of Fit Model

\begin{tabular}{|c|c|c|c|c|}
\hline No & Goodness of Fit Index & Cut of Value & Result & Remarks \\
\hline 1 & DF & $>0$ & 8 & Good Fit \\
\hline 2 & Chi Square & $<\alpha, \mathrm{df}$ & 29.015 & Good Fit \\
\hline 3 & Probability & $>0.05$ & 0.085 & Good Fit \\
\hline 4 & CMIN/DF & $<2$ & 1.627 & Good Fit \\
\hline 5 & GFI & $\geq 0.90$ & 0.950 & Good Fit \\
\hline 6 & AGFI & $\geq 0.90$ & 0.902 & Good Fit \\
\hline 7 & CFI & $\geq 0.90$ & 0.984 & Good Fit \\
\hline 8 & TLI & $\geq 0.90$ & 0.957 & Good Fit \\
\hline 9 & IFI & $\geq 0.90$ & 0.984 & Good Fit \\
\hline 10 & RMSEA & $\leq 0.08$ & 0.02 & Good Fit \\
\hline 11 & NFI & $\leq 0.9$ & 0.978 & Good Fit \\
\hline 12 & HOELTER & $\leq 2.00$ & 36 & Good Fit \\
\hline
\end{tabular}

S o u r c e : Result of AMOS ver 21.

According to B.M. Byrne (2010) the Goodness of Fit Test Model can be continued although there are some models or criteria that have not reached the cut of value, so on that basis, this research can be continued to the next test. It is also supported by Jackson de Carvalho and Chima (2014) who also said similar thing for the research they did in calculating or determining the fit model in a study of Structural Equation Model.

From the Goodness of Fit Test Model (table 1), it can be seen that the model is fit to model the data because there are already 12 (twelve) criteria are met. Thus, the fundamental hypothesis of SEM analysis in this study is accepted which means there is no significant difference between the covariance matrix of the specified model. This shows that the two structural equations produced by the fit model in this research can be used to explain the relationship and influence between exogenous and endogenous variables. While the magni- 
tude of influence of each independent variable on the dependent variable will be tested statistically so it can be known which independent variables are influential and which independent variable gives the most dominant influence to dependent variable.

\section{Hypotheses testing}

Bellow is the table of model testing hypotheses;

Table 2. Hypotheses testing

\begin{tabular}{|ll|l|c|c|c|c|c|}
\hline \hline & & & Estimate & S.E. & C.R. & P & Label \\
\hline \hline Asset & $-->$ & Liquid Asset & 0.401 & 0.021 & 3.888 & $* * *$ & H1 Accepted \\
\hline Profit & $-->$ & Liquid Asset & 0.760 & 0.012 & 6.999 & $* * *$ & H2 Accepted \\
\hline Asset & $-->$ & Value of Shares & 0.120 & 0.023 & 2.002 & $* * *$ & H3 Accepted \\
\hline Liquid Asset & $-->>$ & Value of Shares & 0.780 & 0.380 & 4.502 & $* * *$ & H4 Accepted \\
\hline Profit & $-->>$ & Value of Shares & 0.261 & 0.174 & 3.214 & $* * *$ & H5 Accepted \\
\hline \hline
\end{tabular}

S o u r c e : Result of AMOS ver 21.

According to Supranto and Limakrisna (2013), the structural equations generated by fit models formed from the AMOS 21 output are as follows:

Liquid Asset $=0.401$ Asset +0.760 Profitability

Value of Share $=0.120$ Asset +0.261 Profitability +0.780 Liquid Asset

Based on table 2, it can be seen that the four variables treated using AMOS 21 can be analyzed to know about the influence of each variable. At the stage of research analysis, hypothesis research testing was carried out. The test was conducted for 5 (five) hypotheses submitted. Hypotheses testing was done by using t-value and significance level of 0.05 . The t-value in the AMOS 21 program is the critical ratio (C.R.) in regression weight: (Group number 1 - default model) of the fit model. If the critical ratio value is (c.r.) $>1.967$ or $(-\mathrm{cr}<-1.1967)$ or probability value is $<0.05$ then the research hypothesis is accepted (Haryono \& Wardoyo, 2012, p. 315), as described below. 


\section{Discussion}

\section{The Influence of Asset on Share Value (Hypotheses 1/H1)}

Based on table 2, it can be said that, in the test, the influence between asset variable to share value is known to have p-value 0.000 (***) which is $<0.05$ so that it can be concluded that $\mathrm{H} 1$ is accepted. It means that asset has significantly positive influence on value of stock with a beta coefficient of 0.120 . When beta coefficient has a positive sign, asset variable is in the direction of the variable level of share value. This also means that if each asset variable experiences an increase of one unit, it will increase the share value by 0.120 . The results of this study indicate that the asset has a positive and significant influence on the value of share. This explains that asset has a role in influencing the increase or decrease of share value. Asset as one of the important factors driving the value of stock can be the determinant for investor to invest in a company. A company with large asset is considered capable of providing benefits in the future in the form of return dividend to investor.

This result is supported by the research conducted by Ghauri (2014) which indicated that asset has a significant influence on share value. Another statement by F.N. Al-Shubiri (2010, p. 137) also said that there is a significantly positive relationship between net asset value and stock price.

\section{The Influence of Asset on Liquid Asset (Hypotheses 2/H2)}

Table 2 shows that the influence between asset variable to liquid asset variable has p-value of $0.000\left(^{* * *}\right)$ which is $<0.05$ so that it can be concluded that $\mathrm{H} 2$ is accepted. It means that asset has a significantly positive influence on liquid asset with a beta coefficient of 0.401 because when beta coefficient has a positive sign meaning, asset variable is in the direction of variable level of liquid asset. This also means that if each asset variable experiences an increase of one unit, it will increase the liquid asset by 0.401 . This result is supported by the theory from Soelaiman (2007) which said that assets both current and fixed are the company's properties, such as cash, inventory, fixed asset and others, that play a role in the company's operations. Gill and Mathur (2011) stated that corporate liquidity holding is influenced by the liquidity ratio and firm size. 
The results of this study indicate that asset has positive and significant influence to liquid asset. This is supported by the increase of liquid asset in every increase of the asset of a company, as proposed by Munawir (2004) who said that the liquid asset of a company is inseparable from the influence of asset owned by a company. It can be said all activities that a company runs are from its liquid asset that is illustrated in the company's asset. The research results also conclude that each asset increase by one unit results in the liquid asset increase as much as 0.401 .

\section{The Influence of Profitability on Share Value (Hypotheses 3/H3)}

Table 2 shows that the influence between profit to value of stock has p-value of $0.000{ }^{* * *}$ ) which is $<0.05$ so that it can be concluded that $\mathrm{H} 3$ is accepted. It means that profit has a significantly negative influence to share value with a beta coefficient of 0.261 because when the beta coefficient has a positive sign, it indicates that profit variable is in linear direction with the level of variable share value. Such result means that if each profit variable has an increase by one unit, it will increase the value of share by 0.261 .

The results of this study indicate that profitability has a positive and significant influence on share value. This makes the companies especially the mining sector companies that serve as the object of this research should increase their investments both short and long terms. The results of this study are in line with previous research by Zulia Hanum (2009) which showed that profitability has a significant influence on the movement of share value. This evidence is also supported by Yang, Lee, Gu and Lee (2010) and Sitorus (2016) who shared the same idea.

\section{The Influence of Profitability on Liquid Asset (Hypotheses 4/H4)}

From table 2, it can be seen that the influence between profit variable and liquid asset has a p-value of $0.000\left(^{* * *}\right)$ which is $<0.05$ so that it can be concluded that $\mathrm{H} 4$ is accepted. It means that profit has a significantly negative influence on the liquid asset with a beta coefficient of 0.760 because when the beta coefficient has a negative sign, it indicates that variable of profit is in the opposite direction with variable level of liquid asset. This also means that if profit variable experiences an increase by one unit, it will increase the liquid asset as much as 0.760. This is in accordance with the theory by Agus Sartono (2010) who said 
that profitability is the ability of the company in obtaining profit in relation to sales and this is not apart from the revenue obtained in the form of liquid asset itself. Kasmir (2012) also said that profitability is used to measure the efficiency of the use of corporate asset in the search of profits that culminate in liquid asset that can be used by the company. The results of this study indicate that profitability has negative and significant influence. From such results, it can be concluded that not all companies with high profitability will always have high liquid asset. Therefore, high levels of profitability and liquid asset are necessary to be considered because investor who intends to invest in a company will demand dividend in the form of cash or liquid asset.

\section{The Influence of Liquid Asset on Share Value (Hypotheses 5/H5)}

Based on table 2, it can be said that, in the test, the influence between liquid asset to value of share shows to have p-value of $0.000\left(^{* * *}\right)$ which is $<0.05$ so that it can be concluded that $\mathrm{H} 5$ is accepted. It means that liquid asset has a significantly positive influence on value of stock with a beta coefficient of 0.780 because when beta coefficient that has a positive sign, it indicates that the variable of liquid asset is in the direction of the variable level of share value. This also means that if the liquid asset variable has an increase of one unit then it will increase the share value by 0.780 .

The results of this study indicate that liquid asset as an intervening variable has a positive and significant influence on the value of share. It has been proven that liquid asset has stronger influence than the direct impact of profitability on share value, thereby proving that liquid asset has an important role in a company in managing the amount of asset and profitability targeted by the management in order to achieve the financial objectives of the company. These results are supported by previous research by Utomo (2011) which suggested that cash flow and earnings affect the stock return of a company. This is consistent with the statement of Yocelyn and Christiawan (2012) saying that cash flow and earnings have a significant influence on the value of a company's stock.

Influence analysis is intended to see how strong the influence of a variable with other variables either directly or indirectly. The results of the calculation of direct and indirect influence by AMOS 21 are as bellow: 


\section{Direct Influence}

Table 3. Direct Influence

\begin{tabular}{|l|c|c|c|}
\hline \hline & Profitability & Asset & Liquid Asset \\
\hline \hline Liquid Asset & 0.760 & 0.401 & 1.000 \\
\hline Share Value & 0.261 & 0.120 & 0.780 \\
\hline \hline
\end{tabular}

S o u r c e : Result of AMOS ver 21.

Based on table 3, it can be seen that the largest direct influence is between asset to liquid asset which is 0.401 .The direct influence of asset on the value of share is 0.120 , the direct influence of profitability on the share value is 0.261 and the direct influence of profitability on the liquid asset is 0.760 , while the direct influence of liquid asset on the value of share is 0.780 . Such results are the results of research conducted directly to the value of stock as a dependent variable that is directly influenced by the asset and profitability variable as independent variable in this study.

\section{Indirect Influence}

Table 4. Indirect Influence

\begin{tabular}{|l|c|c|c|}
\hline \hline & Profitability & Asset & Liquid Asset \\
\hline \hline Liquid Asset & 0.000 & 0.0 & 0.000 \\
\hline Share Value & 0.592 & 0.312 & 0.000 \\
\hline \hline
\end{tabular}

S o u r c e : Result of AMOS ver 21.

Based on table 4, it can be seen that the indirect influence of profitability on the value of share is 0.592 , while the indirect influence of profitability variable on liquid asset is 0.0. Indirect influence of asset on liquid asset is also 0.0 and indirect influence of asset on the value of share is 0.312 . Based on table 3 and table 4, it proves that the indirect influence of asset on share value which is 0.312 is stronger than their direct influence which is only 0.120 and the indirect in- 
fluence of profitability on share value which is 0.592 is stronger than their direct influence which is only 0.261 .

From this research, it can be seen that liquid asset as an intervening variable can mediate the asset and profitability toward share value.

\section{CONCLUSION AND IMPLiCATION}

\section{Conclusion}

Based on the results of the research and discussion, some conclusions can be derived and can be summarized as follows: 1). Asset provides a significant positive influence on the value of share. When beta coefficient has a positive sign, it means that an increase in asset value will boost the value of share. These results prove that asset plays a role in influencing the increase of share value, where shareholders will view the high amount of asset owned by a company as a reference to see that the company has the ability to pay dividends to the investors. 2 ). The asset gives significant influence significantly on the liquid asset, and because when the beta coefficient is positive, an increase in asset value will increase the availability of liquid asset. 3). Profitability gives a significantly positive influence on share value. Therefore, the beta coefficient that has a positive mark means that the profit variable is in the same direction as the variable of share value. This also means that if the profit variable increases, it will increase the value of stock. 4). Profitability gives a significantly positive influence on the liquid asset because when beta coefficient has a positive sign, the profitability variable is in the direction of the liquid asset variable. This also means that if the profitability variable increases, it will increase the availability of liquid asset. 5). The liquid asset gives a significant positive influence on the value of stock. When beta coefficient has a positive sign, the liquid asset variable is unidirectional to the variable of value of stock. This also means if the liquid asset variable increases, it will increase the value of stock. Thus, it is clear that liquid asset plays a role as a mediator variable in this study because it has stronger influence than the direct influence of asset and profitability variables on share value.

\section{Implications}

The results of this study can hopefully contribute to form an academic advice that can fill the gap in previous research about the relationship between asset 
variable and share value conducted by Ghauri (2014) and Ruslinda (2013) and between profitability and share value conducted by Sitorus (2016) and Yang et. al (2010), as well as show that liquid asset can act as a mediating variable. Therefore, it is advisable for further research to use liquid asset as the mediating variable because according to what is proposed in this research liquid asset can increase the influence of asset and profitability on share value.

This research also gives practical implication that mining companies in their practices to maintain their liquidity level, especially liquid asset that is obtained from net cash flow, must keep their assets in a safe level as well as their profitability like ROA and ROE as well as net income that can maintain the availability of liquid asset as net cash flow.

\section{Limitations of Research}

Some of the limitations of this study that should be noted for future research are that in this study, observations are still limited, i.e. from 2010-2014 and the samples are only companies that engage in the mining industry. This research did not make any classifications of the length of companies' existence. Further research can be done by adding or extending the study period and the samples as well as classify the length of companies' existence.

\section{REFERENCES}

Agus Sartono, R. (2010). Manajemen Keuangan Teori dan Aplikasi (4th ed.). Yogyakarta: BPFE.

AL-Shubiri, F.N. (2010). Analysis The Determinants Of Market Stock Price Movements: An Empirical Study Of Jordanian Commercial Banks. International Journal of Business and Management, 5(10), 137-147. http://dx.doi.org/10.5539/ijbm.v5n10p137.

Alwi, Iskandar Z. (2003). Pasar Modal, Teori dan Aplikasi. Jakarta: Nasindo Internusa.

Baridwan, Z. (2004). Intermediate Accounting (8th ed.). Yogyakarta: BPFE-UGM.

Brigham, E.F., \& Houston, J.F. (2010). Dasar-Dasar Manajemen Keuangan. Jakarta: Salemba Empat.

Byrne, B.M. (2010). Structural Equation Modeling with AMOS (2nd ed.). New York: Routledge.

Chariri, A., \& Ghozali, I. (2007). Teori Akuntansi. Semarang: Badan Penerbit Universitas Diponegoro.

Damyanti, S., \& Achyani, F. (2006). Analisis Pengaruh Investasi, Likuiditas, Profitabilitas, Pertumbuhan Perusahaan, dan Ukuran Perusahaan Terhadap Kebijakan Div- 
iden Payout Ratio (Studi Empiris pada Perusahaan Manufaktur yang terdaftar di BE). Jurnal Akuntansi dan Keuangan, 5(1), 51-62.

De Carvalho, J., \& Chima, F.O. (2014). Applications of Structural Equation Modeling in Social Sciences Research. American International Journal of Contemporary Research, 4(1), 6-11.

Dyckman, T.R., Davis, C., \& Dukes, R. (2001). Intermediate Accounting (5th ed.). New York: Irwin/McGrawHill.

Elmi, M.A., \& Muturi, W.M. (2016). Effects Of Profitability On Dividend Payout By Commercial And Services Firms Listed In The Nairobi Securities Exchange. European Journal of Business and Social Sciences, 5(2), 160-167.

Ghauri, S.M.K (2014). Determinants of changes in share prices in banking sector of Pakistan. Journal of Economic and Administrative Sciences, 30(2), 121-130. http:// dx.doi.org/10.1108/JEAS-05-2013-0014.

Gill, A., \& Mathur, N. (2011). Factors that Influence Corporate Liquidity Holdings in Canada. Journal of Applied Finance \& Banking, 1(2), 133-153.

Hanum, Z. (2009). Pengaruh Return On Asset (ROA) Return On Equity (ROE) dan Earning Per Share (EPS) Terhadap Price of Saham Pada Perusahaan Otomotif yang terdaftar di Bursa Efek Indonesia Periode 2008-2011. Jurnal Manajemen dan Bisnis, $8(2)$.

Haryono, S., \& Wardoyo, P. (2012). Structural Equation Modeling untuk Penelitian Manajemen Menggunakan AMOS 18.00. Bekasi: PT Intermedia Personalia Utama.

Hermuningsih, S. (2013). Pengaruh Profitabilitas, Growth Opportunity, Sturktur Modal Terhadap Nilai Perusahaan Publik Di Indonesia. Buletin Ekonomi Moneter dan Perbankan, 16(2), 127-148. http://dx.doi.org/10.21098/bemp.v16i2.27.

Kasmir (2012). Analisis Laporan Keuangan. Jakarta: Rajawali Pers.

Kieso, D.E., Weygandt, J.J., \& Warfield, T.D. (2011). Intermediate Accounting. Volume 1 IFRS Edition. Hoboken: Wiley.

Mulya, H. (2010). Memahami Akuntansi Dasar. Edisi 2. Jakarta: Mitra Wacana Media.

Munawir, S. (2004). Analisis Laporan Keuangan. Yogyakarta: LIBERTY.

Naceur, S.B. (2003). The Determinants Of The Tunisian Banking Industry Profitabilitas: Panel Evidence, working paper, http://www.mafhoum.com/press6/174E11.pdf (accessed: 29.05.2018).

Riduwan, O., \& Kuncoro, E.A. (2012). Cara Menggunakan dan Memaknai Path Analysis. Bandung: Alfabeta.

Ruslinda, M. (2013). Pengaruh Rasio Profitabilitas, Age dan Asset terhadap Harga Saham pada Perusahaan Real Estate \& Property (Studi Empiris di Bursa Efek Indonesia Tahun 2007-2010). Semarang: Fakultas Ekonomi \& Bisnis Universitas Dian Nuswantoro.

Sitorus, T. (2016). The Influence of Profitabılity and Debt Ratıo Toward the Value of Stock Mediated by the Issuer's Actıon (Empirical Study on Fishery Companies listed on the Indonesia Stock Exchange period 2008-2014). Asia-Pacific Management and Business Application, 4(3), 96-111. http://dx.doi.org/10.21776/ub.apmba.2016.004.03.1.

Soelaiman, S. (2007). Manajemen Kinerja: Langkah Efektif untuk Membangun, Mengendalikan dan Evaluasi Kerja. Jakarta: PT Intermedia Personalia Utama. 
Stice, E.K., Stice, J.D., \& Skousen, F. (2009). Akuntansi Intermediate. Edisi Keenam Belas. Jakarta: Salemba Empat.

Sugiyono (2011). Metode Penelitian Kuantitatif, kualitatif dan R\&D. Bandung: Alfabeta.

Supranto, J., \& Limakrisna, N. (2013). Petunjuk Praktis Penelitian Ilmiah untuk menyusun skripsi, tesis, dan disertasi edisi dua. Jakarta: Wacana Media.

Suwardjono (2008). Manajemen Keuangan. Edisi Ketiga. Jakarta: Mitra Wacana Media.

Ulupui, I.G.K.A. (2008). Analisis Pengaruh Rasio Likuiditas, Laverage, Aktivitas, dan Profitabilitas terhadap return saham. Jurnal bisnis dan Manajemen, 2, 1-24.

Utomo, S.J. (2011). Analisis Pengaruh Arus Kas Operasi dan Laba Akuntansi terhadap Return Saham Perusahaan Manufaktur di Bursa Efek Indonesia (BEI). Semarang: Universitas Negeri.

Warren, C.S., Reeve, J.M., \& Fess P.E. (2005). Accounting. Jakarta: Salemba Empat.

Yang, C.C., Lee, C.F., Gu, Y.X., \& Lee, Y.W. (2010). Co-determination of capital structure and stock returns - A LISREL approach: An empirical test of Taiwan stock market. The Quarterly Review of Economics, 50(2), 222-233. http://dx.doi.org/10.1016/j. qref.2009.12.001.

Yocelyn, A., \& Christiawan, Y.J. (2012). Analisis Pengaruh Perubahan Arus Kas dan Laba Akuntansi Terhadap Return Saham. Jurnal Akuntansi Dan Keuangan, 14(2), 81-90. http://dx.doi.org/10.9744/jak.14.2.81-90.

Yoo, S., \& Kim, J. (2015). The Dynamic Relationship between Growth and Profitability under Long-Term Recession: The Case of Korean Construction Companies. Sustainability, 7(12), 15982-15998. http://dx.doi.org/10.3390/su71215796.

(www1) IDX 2014 Annual Report, http://www.idx.co.id (accessed 20.01.2016).

(www2) Yahoo Finance, http://finance.yahoo.com (accessed 20.01.2016). 